\title{
Earnings Persistence Over The Macroeconomic Cycle: Evidence From Korea
}

Sorah Park, Ewha Womans University, South Korea

Heejeong Shin, Ewha Womans University, South Korea

\begin{abstract}
This paper examines whether the persistence of earnings components is affected by the macroeconomic cycle in Korea. To measure the macroeconomic cycle, we use the cycle variation value of Coincident Composite Index (CCI) data obtained from the Korea National Statistics Office. Results from a sample of 21,232 firm-quarter observations over the period 2002-2013 indicate that accruals (cash flows) are more persistent than cash flows (accruals) during expansions (recessions). Also, when going from an expansion to a recession, a decline in accruals persistence is greater than that in cash flows persistence. When total accruals are decomposed into non-discretionary and discretionary portions using the modified Jones model (Dechow et al., 1995), we find that non-discretionary accruals are most persistent than the other components during both expansions and recessions, and a decline in persistence is largest (smallest) for discretionary accruals (cash flows) when going from an expansion to a recession. Most of these results hold when we split the macroeconomic cycle into four phases including transitory periods. Taken together, we provide evidence on the differential effects of macroeconomic cycle on the persistence of individual earnings components in Korea. Our findings suggest that macroeconomic variables are needed to be considered in studies on earnings persistence.
\end{abstract}

Keywords: Earnings Persistence; Macroeconomic Cycle; Business Cycle; Earnings Components

\section{INTRODUCTION}

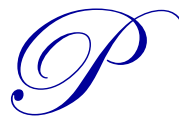

ersistent earnings are recurring and sustainable, thus considered desirable by capital market participants (e.g., Penman and Zhang, 2002; Richardson, 2005). For instance, equity investors view persistent earnings as useful and informative inputs for equity valuation. As shown by prior research (e.g., Kormendi and Lipe, 1987; Easton and Zmijewski, 1989), the magnitude of stock price reaction to earnings surprise (i.e., earnings response coefficient; ERC) is positively related to earnings persistence. Also, firms with more persistent earnings generally experience lower cost of equity capital than those with less persistent earnings (e.g., Francis et al., 2004).

Moreover, prior research (e.g., Dechow et al., 1995; Sloan, 1996; Xie, 2001) documents that accruals persistence is lower than cash flows persistence and investors do not fully reflect such differential persistence in firm valuation, which leads to accruals anomaly. Dechow et al. (2010) argue that earnings that are predominantly composed of accruals are less persistent than earnings that are predominantly composed of cash flows (p. 354). Also, for companies with high (low) accruals, accruals increase (reduce) the persistence of earnings relative to cash flows (Dechow and Ge, 2006). In addition, Dechow et al. (2008) find that cash flows related to payment for or issuance of equities are the major determinant of high persistence of cash flows relative to accruals.

Macroeconomic conditions are also likely to have impacts on earnings persistence. According to Dichev et al. (2013), CFOs perceive macroeconomic conditions to be highly influential in determining the quality of earnings, above internal controls and the board of directors (p. 17). In one of earlier studies, Johnson (1999) finds evidence 
that earnings persistence is positively associated with both economic growth rates and the level of economic activity. Recently, Tomy (2012) argues that changing economic climate would affect not only firm fundamentals but also incentives of participants to the financial reporting process, thereby affecting earnings persistence which is driven by both fundamentals and accounting system (p. 2). Based on the U.S. data, he shows that earnings persistence declines when going from an expansion to a moderate growth phase and then to a recession.

The evidence suggesting a link between earnings persistence and macroeconomic cycle has been documented in Korea, but it is limited to the relation between accruals and macroeconomic cycle. For instance, Lee (2010) argues that the difference of long-term net-operating assets (NOA) across the business cycle affects accruals persistence. His findings show that accruals persistence is lower in recessions than in expansions due to a decrease in marginal profits available for new investments during economic downturn. Also, Kwon et al. (2012) find that positive associations between managers' forecast errors and current accruals strengthen as the market uncertainty (proxied by macroeconomic variables such as production activities and interest rates) increases. Such findings indicate that managers' forecast errors during uncertain times may induce high magnitude of current accruals, which in turn may decrease the persistence of earnings. However, studies that analyze the persistence of specific earnings components (i.e., cash flows, non-discretionary accruals and discretionary accruals) with the consensual definition of macroeconomic cycle are absent in Korea.

Therefore, this paper examines whether the persistence of earnings components is affected by the macroeconomic cycle in Korea. We decompose earnings into cash flows, non-discretionary accruals and discretionary accruals components in order to show how persistence of different components of earnings is related to the changing climate of the economy. Also, we split macroeconomic cycle into two aspects (expansion and recession) and further into four aspects (expansion, transitory period from expansion to recession, recession, and transitory period from recession to expansion) by following the definition used in Tomy (2012). Moreover, we investigate whether the magnitude of changes in persistence across the macroeconomic cycle differs by individual earnings components.

Results from a sample of 21,232 firm-quarter observations over the period 2002 Q4-2013 Q3 indicate that earnings persistence varies with the business cycle, supporting our hypotheses. Sample firms consist of KOSPI and KOSDAQ companies, and business cycle is measured using the cycle variation value of Coincident Composite Index data obtained from the Korea National Statistics Office. We show that accruals (cash flows) are more persistent than cash flows (accruals) during expansions (recessions), and a decline in accruals persistence is greater than one in cash flows persistence when going from an expansion to a recession. Larger magnitude of a decline in accruals persistence implies that macroeconomic cycle is more influential on accruals than on cash flows. When total accruals are decomposed into non-discretionary and discretionary accruals by using the modified Jones model (Dechow et al., 1995), we find that non-discretionary accruals are more persistent than cash flows and discretionary accruals in both expansions and recessions. In addition, when going from an expansion to a recession, a decline in persistence is largest for discretionary accruals, and it is smallest for cash flows.

When we split the business cycle into four aspects, we still show that accruals (cash flows) are more persistent than cash flows (accruals) during expansions (recessions) and that the magnitude of changes across the business cycle is largest for accruals. Furthermore, non-discretionary accruals are more persistent than cash flows and discretionary accruals in all phases of the business cycle. Lastly, when the economy shrinks (i.e., from a transitory period to a recession), we find that a decline in persistence is largest for discretionary accruals, whereas when the economy recovers (i.e., from a recession to a transitory period), an increase in persistence is largest for non-discretionary accruals. This finding indicates the differential effects of macroeconomic cycle on the persistence of individual earnings components.

Our findings have several contributions. First, this study sheds light on the complex interaction between macroeconomic cycle and firm valuation by documenting the variation of earnings persistence over the business cycle. Our findings suggest that predicting future earnings with consideration of macroeconomic cycle would

decrease market participants' mispricing of a firm. Also, the evidence in this study suggests that macroeconomic variables should be considered in research on earnings persistence, thereby adding to the prior research such as Tomy (2012). 
The remainder of the paper is organized as follows. Section 2 summarizes prior studies on earnings persistence and business cycle and motivates the research question. Section 3 develops the hypotheses. Section 4 discusses the sample and variable measurement. Section 5 presents the empirical results, and finally Section 6 concludes.

\section{PRIOR LITERATURE AND MOTIVATIONS}

\section{Earnings Persistence and Firm Valuation}

Prior studies on earnings quality provide different definitions of earnings quality and report their empirical findings based on different proxies of earnings quality (Dechow et al., 2010). A large volume of research defines earnings quality in an equity valuation context (e.g., Healy and Wahlen, 1999; Dechow and Skinner, 2000; McNichols, 2000; Fields et al., 2001). Dechow et al. (2010) define that "higher quality earnings provide more information about the features of a firm's financial performance that are relevant to specific decision makers" (p. 344). ${ }^{1}$ They argue that persistent and sustainable earnings are better indications of future cash flows, and therefore useful inputs for equity valuation. Penman and Zhang (2002), Dechow and Schrand (2004) and Melumad and Nissim (2009) also define that high quality earnings are persistent, thus playing a crucial role in predicting future earnings in the long run.

Because of a link between earnings persistence and firm valuation, companies may have incentives to manage earnings. Since firms that consistently meet or beat prior-period earnings or analyst forecasts are rewarded with higher stock prices (Barth et al., 1999; Kasznik and McNichols, 2002; Myers et al., 2007), managers are likely to manipulate earnings upward or downward to report persistent earnings. ${ }^{2}$ In particular, income smoothing strategies through altering accounting choices or methods could be implemented to meet the market's earnings expectation (Defond and Park, 1997) or to beat analyst forecasts. However, managers could also choose to report less persistent earnings by taking a big bath, thereby writing off an asset value in order to clean up the balance sheet for positive future earnings (Elliot and Shaw, 1988; Erickson and Wang, 1999). ${ }^{3}$

Moreover, prior research (e.g., Dechow et al., 1995; Sloan 1996; Xie, 2001; Fairfield et al., 2003) documents that persistence is differential among earnings components and market participants do not fully reflect such differential persistence in firm valuation. Sloan (1996) reports that accruals persistence is less than cash flow persistence and investors underweight this property of earnings, leading to accruals anomaly. By extending Sloan (1996), Xie (2001) finds that low accruals persistence is largely due to discretionary accruals which are measured by the modified Jones model (Dechow et al., 1995). On the other hand, Fairfield et al. (2003) view accruals as "a component of net operating assets" (p. 355), and argue that low accruals persistence is due to the growth effect (i.e., diminishing marginal profits available for new investments). Similarly, Richardson et al. (2006) argue that if accruals reflect real investment growth, then the growth will lead to higher sales; however, if accruals increase without sales growth, then an increase in accruals is due to either distortion of accounting numbers or a less efficient use of capital. The diminishing marginal returns explanation for accruals predicts a relation between an increase in accruals and sales growth.

Earnings persistence is affected by both the magnitude and sign of the accruals (Dechow and Ge, 2006, p. 254). Dechow et al. (2010) argue that earnings that are predominantly composed of accruals are less persistent than earnings that are predominantly composed of cash flows. Also, Richardson et al. (2005) decompose financial statements into short-term and long-term operating assets/liabilities and financial assets/ liabilities. They show that short-term accrual components are less persistent than long-term components and financial accruals are more persistent than operating accruals. Moreover, Dechow and Ge (2006) argue that accruals increase the persistence of earnings for high accrual firms, but reduce earnings persistence for low accrual firms. Specifically, they show that

\footnotetext{
${ }^{1}$ Dechow et al. (2010)'s definition suggests that earnings quality could be evaluated with respect to any decision that depends on an informative representation of financial performance. It does not constrain earnings quality to imply decision usefulness in the context of equity valuation.

${ }^{2}$ There are many incentives for earnings management from the market valuation perspective and executive compensation perspective. This study is focused on the market valuation consequences of earnings quality.

${ }^{3}$ Since earnings persistence varies with the firm fundamentals, information embedded in earnings persistence is useful for stakeholders to predict future earnings and then to prevent mispricing of firm value (Chen, 2011; Tomy, 2012).
} 
low earnings persistence of low accrual firms is primarily driven by special items. ${ }^{4}$ In addition, prior research has identified cash flow components as the driver of high persistence relative to accrual components. For instance, Dechow et al. (2008) show that cash flows related to payment for or issuances of equities are the major determinant of higher persistence of the cash flow components relative to accrual components. In sum, many factors affecting earnings persistence are related to the property of earnings such as the relative weight of accruals to cash flows or persistence of individual components of earnings.

\section{Earnings Forecasts and Macroeconomic Condition}

Many prior studies (e.g., Bradshaw et al., 2001; Mikhail et al., 2003; Hutton et al., 2012) have reported that earnings are sensitive to macroeconomic news such as GDP growth rates. According to Hess and Kreuzmann (2009), "companies' realized earnings depend on overall economic conditions" (p. 1). Hugon et al. (2013) also argue that macroeconomic factors have major impacts on corporate earnings. Moreover, assuming that changes in overall business conditions are related to information components in macroeconomic conditions, Agarwal and Hess (2012) argue that the effects of changing business conditions on future earnings are not negligible for asset pricing (p. 7).

While macroeconomic condition is an effective factor in predicting a firm's future performance, market participants and information intermediaries (such as analysts) are shown to underreact to macroeconomic news (Darrough and Russell, 2002; Hess and Kreutzmann, 2009; Mckinsey, 2010; Hann et al., 2011; Agarwal and Hess, 2011; Hugon et al., 2013). For example, Darrough and Russell (2002) find that analysts fail to forecast earnings downward in response to the market crash in 1987 and the Asian financial crisis in 1997. Hann et al. (2011) find that analysts' forecast errors are predictably more negative than those of economists following the negative economic news, suggesting that analysts underreact to negative macroeconomic news and then stock market overweighs on analysts' earnings forecast. Hugon et al. (2013) also find that analysts underreact to negative macroeconomic news and their forecasts are more efficient when there are in-house macro-economists.

Because analysts' forecasts represent the market's expectation and their forecast revision represents the market's reaction to the news, such prior findings imply that most market participants would underreact to macroeconomic conditions as one of determinants of earnings persistence.

\section{Motivations: Earnings Persistence and Macroeconomic Cycle}

Prior literature suggests that determinants of earnings persistence may be affected by macroeconomic conditions. However, as discussed in the previous section, market participants or analysts underreact to the effect of macroeconomic conditions in predicting future earnings. Since a manager's prediction of future earnings is largely reflected in current accruals when there is a massive uncertainty in business environments (Guay et al., 1996; Subramanyam, 1996), this implies that managers' forecast errors in high uncertainty periods (such as a recession) could lead to low earnings persistence.

In fact, Dichev et al. (2013)'s survey reports that CFOs rank macroeconomic condition as a highly influential factor in determining the quality of earnings. CFOs also respond that sustainable earnings are high quality earnings, ranking earnings persistence as the third most important property of earnings (Dichev et al., 2013, p. 13).

There are several empirical studies investigating the relation between macroeconomic condition and earnings persistence. Lev and Thiagarajan (1993) show that value relevance of 12 fundamental signals for future earnings varies across the level of macroeconomic conditions (i.e., inflation rate and GDP growth). Also, Johnson (1999) examines the business cycle variation in the earnings-returns relation. She documents that earnings persistence and ERCs vary with the changes in the aggregate financing opportunity set, thus with the business

\footnotetext{
${ }^{4}$ Special items are accrual adjustments that reduce the persistence of earnings as well as accrual components (Nissim and Penman, 2001; Fairfield et al., 2003; Dechow and Ge, 2006; Allen et al., 2009). Previous studies show that low accrual firms with large special items have higher future stock returns than other low accrual firms. This is consistent with investors misunderstanding the transitory nature of special items.
} 
cycle. $^{5}$ Specifically, earnings persistence is higher in expansions than in recessions, and is higher in credit crunch periods than in reliquification periods. Both Lev and Thiagarajan (1993) and Johnson (1999) support the importance of a contextual analysis of financial statement information, suggesting a link between earnings persistence and individual macroeconomic variables. Tomy (2012) analyzes more directly the relationship between earnings persistence and the macroeconomic cycle. He decomposes earnings into accruals and cash flows components, and finds that persistence of individual earnings components shows a similar pattern to earnings persistence. Specifically, cash flows are more persistent than accruals during expansionary times. Also, the difference between cash flows and accruals persistence seems to vary with the phase of the business cycle. ${ }^{6}$

The evidence suggesting a link between earnings persistence and macroeconomic condition has been reported by several studies in Korea (e.g., Lee, 2010; Kwon et al., 2012). Kwon et al. (2012) find that positive associations between managers' forecast errors and current accruals strengthen as there is more uncertainty in the market (proxied by macroeconomic variables such as production activities and interest rates based on Kim and Qi (2010)). Based on their findings, we conjecture that managers' forecast errors in uncertain times could induce higher magnitude of current accruals, which in turn may decrease the persistence of earnings. Also, Lee (2010) provides more direct evidence that accruals anomaly and accruals persistence are influenced by business cycle. Since net operating assets (NOA) are composed of accruals, the difference of long-term NOA over the business cycle affects accruals persistence and consequently accruals anomaly. Specifically, accruals persistence is shown to be lower during recession periods than expansion periods because of a decrease in marginal profits available for new investments during recessions. Taken together, these prior studies find that accruals persistence varies with business cycle. However, studies that analyze the persistence of specific earnings components (i.e., cash flows, nondiscretionary accruals and discretionary accruals) with the consensual definition of macroeconomic cycle are absent in Korea.

Therefore, this paper examines whether the persistence of earnings components is affected by the macroeconomic cycle in Korea. We decompose earnings into cash flows, non-discretionary accruals and discretionary accruals components in order to show how persistence of different components of earnings is related to the changing climate of the economy. Also, we split the macroeconomic cycle into two aspects (expansion and recession) and further into four aspects (expansion, transitory period from expansion to recession, recession, and transitory period from recession to expansion), following the definition of Tomy (2012).

\section{HYPOTHESES DEVELOPMENT}

Since Sloan (1996) showed that accruals are less persistent than cash flows, many studies have discovered the reasons for lower persistence of accruals. Xie (2001) reports that discretionary accruals (which involve manager's judgment) are less persistent than non-discretionary accruals (which are largely a firm's operational result). In this context, Richardson et al. (2005) find that working capital and non-current accruals are less persistent than financial accruals. Fairfield et al. (2003) argue that lower persistence of accruals, which are a component of NOA, is attributed to accounting conservatism and lower persistence of NOA growth (p. 369). Lastly, Dechow and Ge (2006) show that lower accruals persistence in low accrual firms is mainly driven by transitory nature of special items. Collectively, accruals persistence is affected by the variation in magnitude and sign of accrual items or transitory property of a certain component of accruals.

Literature suggests that accruals persistence is related to firm-specific activities as well as operational environments (i.e., market uncertainty). Chan et al. (2006) document that low persistence of accruals is largely due to inventories, receivables and debt accruals. Furthermore, Dichev et al. (2013)'s survey of CFOs suggests that most factors affecting accruals persistence are influenced by economy-wide conditions. For instance, when business cycle enters an expansionary period, sales and production of firms increase and in turn accruals such as net operating

\footnotetext{
${ }^{5}$ Johnson (1999) describes the aggregate financing opportunity set assuming that the economy moves through the business cycle from expansion, to credit crunch, to recession, to reliquification, and then to the following expansion labeled by the National Bureau of Economic Research (NBER) and Data Resources, Inc. (DRI).

${ }^{6}$ Tomy (2012) classifies the business cycle into four phases: expansion, first transition, recession, and second transition period. He defines two quarters each before and after recessionary period (which is labeled by NBER) to be transition period. Note that we follow his definition of business cycle in this paper.
} 
assets (i.e., inventories, receivables and debt accruals) increase. Contrarily, when business cycle enters a recessionary period, the reversal occurs. Moreover, when business cycle moves across the stages, managerial incentives to manipulate earnings may change and therefore affect persistence of operating assets (which are classified as non-discretionary accruals) and discretionary accruals. Specifically, when market-wide conditions change drastically, managers are likely to implement income smoothing strategy to manage earnings upward or downward using discretionary accruals for the purpose of higher market valuation. Or, they may take a big bath in case when their firms incur heavy losses so that they can increase future earnings. This implies that persistence of earnings, composed of accruals and cash flows, may be affected by state-varying factors surrounding a company.

Therefore, we hypothesize that earnings persistence is systematically different over the business cycle. Specifically, earnings persistence is expected to be higher in expansions than in recessions. During recessionary periods, there is great uncertainty about firm performance and many firms would experience financial distress. Then, corporate sales and investments would decrease and firms may cut expenditures and adjust production downward to meet their sales level (Johnson, 1999; Klein and Marquardt, 2006; Tomy, 2012). On the other hand, during expansionary periods, firms would have greater sales, production and investments, which could lead to an increase in accruals such as NOA. Since firms with larger accruals have more persistent accruals (as shown by Dechow and $\mathrm{Ge}(2006))$, this suggests that accruals will be more persistent in expansions than in recessions.

Moreover, prior literature decomposes total accruals into discretionary and non-discretionary portions. Discretionary accruals are estimated in a manner that they are remainders of total accruals except for nondiscretionary accruals composed of net operating assets such as inventories, receivables and debt (e.g., Jones, 1991; Dechow et al., 1995). During recessions, managers' pessimistic expectation of future earnings would provide incentives to manage earnings via accruals adjustment. However, during expansions, managers are more optimistic in predicting future earnings, thus they are less likely to engage in earnings management. Therefore, we predict that persistence of discretionary and non-discretionary accruals will differ by macroeconomic cycle. The first hypothesis is stated as follows:

H1: Earnings (cash flows, non-discretionary and discretionary accruals) persistence is systematically different over the macroeconomic cycle.

Next, we predict that the magnitude of changes in persistence across macroeconomic cycles is likely to be different between cash flows and accruals. Cash flows components are determined by cash transactions which involve a firm's operating activities and, therefore, considered as a measure of a firm's real performance (Klein and Marquardt, 2006). This implies that cash flows component of earnings is less sensitive to the macroeconomic conditions than accruals component. Thus, we conjecture that the magnitude of changes in cash flows persistence across macroeconomic cycles will be smaller than that in accruals persistence.

While cash flows persistence is affected mostly by a firm's operational environment, accruals persistence is likely to be affected not only by a firm's operating activities but also by accounting choices intended for income smoothing, higher executive compensation, or tax avoidance (Baber et al., 1998; Healy and Wahlen, 1999; Nwaeze et al., 2006). Also, as shown by prior research (Martin, 2008a; Martin, 2008b; Lee, 2010; Kwon et al., 2012), accruals component of earnings is sensitive to the variation in macroeconomic conditions. Therefore, we predict the magnitude of changes in accruals persistence to be larger than that of cash flows when going from an expansion to a recession. 
Moreover, we expect the effects of macroeconomic cycle on non-discretionary accruals and discretionary accruals to be differential. Prior research (e.g., Jones, 1991; Rangan, 1998; Teoh et al., 1998) has shown that discretionary portion of accruals is used for earnings management, and managerial incentives to manipulate earnings are likely to be greater in economic downturns (Tomy, 2012). On the other hand, "within the confines of the accounting system, non-discretionary accruals are perhaps most reflective of underlying fundamentals" (Tomy, 2012, p. 13). This implies that the magnitude of changes in discretionary accruals persistence will be greater than that of non-discretionary accruals when going from an expansion to a recession. Therefore, our second hypothesis is stated as follows:

H2: The magnitude of changes in persistence across the states of the economy differs by individual earnings components.

\section{RESEARCH METHODOLOGY}

\section{Data and Sample Selection}

We retrieve quarterly earnings data from Kisvalue II database of NICE Investors Service Co, Ltd (http://www.niceinfo.co.kr/business/KISVALUE.nice) in Korea from 2002 Q4 to 2013 Q3. ${ }^{7}$ To measure the business cycle, we obtain the cycle variation value of Coincident Composite Index (CCI) at monthly level from the Korea National Statistics Office (http://www.kostat.go.kr). While prior studies have used gross domestic product (GDP) growth or interest rates as the proxy of macroeconomic condition, such individual macroeconomic variables have limitations in representing overall economic conditions. Thus, we consider the cycle variation of CCI as a more comprehensive indicator of overall macroeconomic conditions since it reflects several economic dimensions such as production, consumption, investment, and employment etc. ${ }^{8}$ We calculate quarterly average of monthly figures of the cycle variation value of CCI, and define the business cycle as an expansion if the quarterly average is above 100 points and a recession otherwise.

Of a total of 32,650 quarterly observations with fiscal year-end in December during the period 2002 Q4 to 2013 Q3, we impose the following restrictions: (1) delete firms that belong to financial and insurance industries, (2) delete firms with impairment of capital, (3) delete if number of industry-year observations is less than 10, (4) delete observations with missing total assets or earnings. The final sample is 21,232 firm-quarter observations. Table 1 presents the sample selection criteria.

Table 1. Sample Selection Criteria

\begin{tabular}{lc}
\hline \multicolumn{1}{c}{ Sample Selection Criteria } & Firm-quarters Observations \\
\hline Observations with December fiscal year-ends and non-financial and non-insurance industry & 32,650 \\
during the period 2002 Q4 to 2013 Q3 & $(1,643)$ \\
Less: observation with impairment of capital & $(190)$ \\
Less: industry-year combination with less than 10 observations 9 & $(9,585)$ \\
Less: observations with missing total assets or earnings variables & 21,232 \\
Final Sample & \\
\hline
\end{tabular}

\section{Variable Measurement}

The financial variables of interest are earnings, accruals and cash flows from operations (CFO). Total accruals are defined as follows: $A C C_{i, t}=E A R N_{i, t}-C F O_{i, t}$, where $A C C_{i, t}$ represents total accruals for firm $i$ in $t$ year-quarter, $E A R N_{i, t}$ represents net income for firm $i$ in $t$ year-quarter from income statement, and $C F O_{i, t}$ denotes

\footnotetext{
${ }^{7}$ Quarterly disclosure of cash flows statement has been required starting fiscal year 2002 in Korea.

${ }^{8}$ Coincident Composite Index (CCI) is measured as the aggregate index composed of seven variables (industrial production, manufacturing operation ratio, producer's shipment, wholesale and retail return on sales, non-durable consumption goods shipment, the amount of imports, the cement consumption and the number of employees in non-farm household). The cycle variation value of CCI is considered as the indicator of a current phase of business cycle, because it excludes the changes in drift due to economic growth (http://kostat.go.kr/portal/korea/index.action).

${ }^{9}$ This step is necessary for the regression to estimate discretionary accruals based on the modified Jones Model (Dechow et al., 1995).
} 
cash flows from operation for firm $i$ in $t$ year-quarter, which is reported on statement of cash flows. All variables are scaled by average total assets at the end of the prior year.

Next, we estimate non-discretionary and discretionary accruals by using the modified Jones model (Dechow et al., 1995). ${ }^{10}$ We estimate the following regression equation (1) to obtain coefficient estimates that are needed to measure non-discretionary portion of total accruals.

$$
T A C C_{t}=\alpha_{1}\left(\frac{1}{A_{t-1}}\right)+\alpha_{2}\left(\Delta R E V_{t}-\Delta R E C_{t}\right)+\alpha_{3}\left(P P E_{t}\right)+v_{t}
$$

where,

$T A C C_{t} \quad$ : Total accruals in year-quarter $t$ scaled by total assets at year-quarter $t-1$

$\triangle R E V_{t} \quad$ : Revenues in year-quarter $t$ less revenues in year-quarter $t-1$ scaled by total assets at year-quarter $t-1$

$\triangle R E C_{t}$ : Net receivable in year-quarter $t$ less net receivable in year-quarter $t-1$ scaled by total assets at year-quarter $t-1$

$P P E_{t} \quad$ : Gross property plant and equipment in year-quarter $t-1$ scaled by total assets in year-quarter $t-1$

$A_{t-1} \quad:$ Total assets at year-quarter $t-1$

$v_{t} \quad$ : Residuals in year-quarter $t$

Then, non-discretionary accruals are estimated based on the following equation (2) and discretionary accruals are measured as the difference between total accruals and non-discretionary accruals as in equation (3).

$$
\begin{aligned}
& N D A_{t}=\widehat{\alpha_{1}}\left(\frac{1}{A_{t-1}}\right)+\widehat{\alpha_{2}}\left(\Delta R E V_{t}-\Delta R E C_{t}\right)+\widehat{\alpha_{2}}\left(P P E_{t}\right) \\
& D A_{t}=T A C C_{t}-N D A_{t}
\end{aligned}
$$

where,

$N D A_{t} \quad$ : Non-discretionary accruals in year-quarter $t$

$D A_{t} \quad$ : Discretionary accruals in year-quarter $t$

\section{Test Models}

Earnings persistence is measured as the slope coefficient from a regression of current earnings on lagged earnings. If earnings are highly persistent, this slope coefficient is likely to be close to one. We analyze earnings persistence over the business cycle by estimating the modified version of regression models with an indicator variable for a recession that represents a macroeconomic shock to the earnings stream.

Model 1: $E A R N_{i, t}=\alpha_{0}+\alpha_{1} R_{t-1}+\alpha_{2} E A R N_{i, t-1}+\alpha_{3} R_{t-1} * E A R N_{i, t-1}+\epsilon_{i, t}$

Model 2: $E A R N_{i, t}=\alpha_{0}+\alpha_{1} R_{t-1}+\alpha_{2} A C C_{i, t-1}+\alpha_{3} R_{t-1} * A C C_{i, t-1}+\alpha_{4} C A S H_{i, t-1}+\alpha_{5} R_{t-1} * C A S H_{i, t-1}+\epsilon_{i, t}$

where, $E A R N_{i, t}$ is net income of firm $i$ in quarter-year $t, R_{t}$ is an indicator variable that equals one if quarter-year $t$ belongs to recessionary periods and zero otherwise, $A C C_{i, t}$ represents total accruals of firm $i$ in quarter-year $t$, $C A S H_{i, t}$ is operating cash flows of firm $i$ in quarter-year $t$.

Hypothesis 1 predicts that earnings persistence is systematically different over the business cycle. If model 1 provides the result supporting this hypothesis, that is, earnings persistence is higher in expansions than in recessions, we will find $\alpha_{2}>0$ and $\alpha_{3}<0$. Also, we expect that persistence in cash flows is greater than

\footnotetext{
${ }^{10}$ Dechow et al. (1995) suggest that the modified Jones model provides the most powerful test for detecting earnings management as compared to other discretionary accruals models. Recent studies (e.g., Linck et al., 2013; Huang et al., 2014) demonstrate the validity of this measurement of abnormal accruals. Therefore, our study estimates discretionary accruals based on the modified Jones model (Dechow et al., 1995).
} 
persistence in accruals $\left(\alpha_{4}>\alpha_{2}\right)$ in model 2. If persistence of earnings components is higher in expansions than in recessions, then we will find $\alpha_{3}<0$ and $\alpha_{5}<0$ in model 2 .

Hypothesis 2 predicts that the magnitude of changes in accruals persistence when going from an expansion to a recession is higher than that in cash flows persistence. If model 2 provides the result supporting this hypothesis, a decline in accruals persistence during recessions will be presumably greater than one in cash flows persistence $\left(\alpha_{3}>\alpha_{5}\right)$.

Next, we further decompose total accruals into discretionary and non-discretionary accruals in the models:

Model 3: EARN $_{i, t}=\alpha_{0}+\alpha_{1}$ DISC $_{i, t-1}+\alpha_{2} \operatorname{NONDISC}_{i, t-1}+\alpha_{3}$ CASH $_{i, t-1}+\epsilon_{i, t}$

Model 4: EARN $_{i, t}=\alpha_{0}+\alpha_{1} R_{t-1}+\alpha_{2}$ DISC $_{i, t-1}+\alpha_{3} R_{t-1} *$ DSIC $_{i, t-1}+\alpha_{4}$ NONDISC $_{i, t-1}$

$$
+\alpha_{5} R_{t-1} * \text { NODISC }_{i, t-1}+\alpha_{6} \text { CASH }_{i, t-1}+\alpha_{7} R_{t-1} * \mathrm{CASH}_{i, t-1}+\epsilon_{i, t}
$$

where, $E A R N_{i, t}$ is net income of firm $i$ in quarter-year $t, R_{t}$ is an indicator variable that equals one if quarter-year $t$ belongs to recessionary periods and zero otherwise, $D I S C_{i, t}$ represents discretionary accruals of firm $i$ in quarter-year $t, N O N D I S C_{i, t}$ represents non-discretionary accruals of firm $i$ in quarter-year $t, C_{A S H}$ is operating cash flows of firm $i$ in quarter-year $t$.

Model 3 is used as a benchmark test on the persistence of discretionary accruals, non-discretionary accruals and cash flows, without conditioning on the business cycle. As suggested by prior literature, we expect to find persistence of cash flows and non-discretionary accruals to be greater than discretionary accruals $\left(\alpha_{3}, \alpha_{2}>\alpha_{1}\right)$. The result of comparison between cash flows persistence and non-discretionary accruals persistence is an open question. ${ }^{11}$

If model 4 provides the result supporting our first hypothesis, that is, discretionary, non-discretionary accruals and cash flow persistence are higher in expansions than in recessions, we will find negative signs for $\alpha_{3}$, $\alpha_{5}$, and $\alpha_{7}$. Also, hypothesis 2 predicts that the incremental negative effects of recession on persistence of individual earnings components (i.e., the magnitude of $\alpha_{3}, \alpha_{5}$, and $\alpha_{7}$ ) are different each other. The result of comparison between $\alpha_{3}, \alpha_{5}$, and $\alpha_{7}$ is also an open empirical question.

\section{EMPIRICAL RESULTS}

\section{Descriptive Statistics and Correlation Analysis}

Table 2 reports descriptive statistics of earnings across the business cycle. Panel A presents the mean of key variables (the cycle variation value of CCI, earnings, total accruals, cash flow from operations, discretionary accruals and non-discretionary accruals) during the sample period. We find that all variables tend to follow a cyclical pattern by the business cycle. ${ }^{12}$ Panel B shows the summary statistics of earnings components (total accruals, cash flows, discretionary accruals, and non-discretionary accruals) for two phases of business cycle. The mean and median of earnings and operating cash flows are larger during recessions than during expansions, whereas those of accruals (total, non-discretionary, discretionary) are larger during expansions than during recessions.

\footnotetext{
${ }^{11}$ The results of correlation analysis reported in Table 3 present that the correlation of the prior quarter's cash flow with current earnings is stronger than the correlation of the prior quarter's non-discretionary accruals with current earnings. However, as stated above, it is likely that these results may be attributable to the correlation analysis with some lack of influential control variables to affect current earnings.

${ }^{12}$ A partial phase of business cycle (i.e., expansion or recession) tends to last 12 to 24 months on average, except for 2003 . This is nearly consistent with the report of the Korea National Statistics Office that the whole cycle lasts about 49 months (Han, 2006).
} 
Table 2. Descriptive Statistics

\begin{tabular}{|c|c|c|c|c|c|c|c|c|}
\hline $\begin{array}{c}\text { PERIOD } \\
\text { (Year. Quarter) }\end{array}$ & BC & CCI & $\mathbf{N}$ & $E A R N$ & $A C C$ & CFO & DISC & $\begin{array}{c}\text { NONDIS } \\
C\end{array}$ \\
\hline 2003.1 & EXP & 101.18 & 283 & 0.0141 & 0.0068 & 0.0073 & -0.0009 & 0.0077 \\
\hline $2003.2 \sim 2003.3$ & REC & 99.78 & 763 & 0.0327 & 0.0033 & 0.0294 & 0.0103 & -0.0070 \\
\hline 2003.4 2004.2 & EXP & 101.01 & 1310 & 0.0296 & -0.0027 & 0.0323 & 0.0004 & -0.0032 \\
\hline $2004.3 \sim 2006.3$ & REC & 99.17 & 4167 & 0.0324 & 0.0003 & 0.0321 & 0.0037 & -0.0034 \\
\hline $2006.4 \sim 2008.3$ & EXP & 101.56 & 3445 & 0.0285 & 0.0044 & 0.0241 & 0.0044 & 0.0000 \\
\hline 2008.4 2009.4 & REC & 97.87 & 3062 & 0.0281 & -0.0107 & 0.0389 & -0.0019 & -0.0085 \\
\hline $2010.1 \sim 2012.1$ & EXP & 100.68 & 4855 & 0.0263 & 0.0071 & 0.0191 & 0.0041 & 0.0030 \\
\hline 2012.1 2013.9 & REC & 99.24 & 3347 & 0.0177 & -0.0089 & 0.0266 & 0.0013 & -0.0103 \\
\hline
\end{tabular}

Panel B. Descriptive Statistics across Two Phases of Business Cycle

\begin{tabular}{|c|c|c|c|c|}
\hline & & POOLED & EXP & REC \\
\hline & MEAN & $0.0271 * * * b)$ & $0.0261 * * *$ & $0.0279 * * *$ \\
\hline \multirow[t]{2}{*}{$E A R N$} & MEDIAN & 0.0219 & 0.0208 & 0.0231 \\
\hline & STD & 0.0548 & 0.0477 & 0.0602 \\
\hline \multirow{3}{*}{$A C C$} & MEAN & $0.0002 * * *$ & $0.0057 * * *$ & $-0.0045^{* * *}$ \\
\hline & MEDIAN & -0.0010 & 0.0032 & -0.0047 \\
\hline & STD & 0.0708 & 0.0665 & 0.0740 \\
\hline \multirow{3}{*}{ CFO } & MEAN & $0.0269 * * *$ & $0.0204 * * *$ & $0.0325 * * *$ \\
\hline & MEDIAN & 0.0220 & 0.0168 & 0.0271 \\
\hline & STD & 0.0691 & 0.0679 & 0.0697 \\
\hline \multirow{3}{*}{ DISC } & MEAN & $0.0031 * * *$ & $0.0044 * * *$ & $0.0019 * * *$ \\
\hline & MEDIAN & 0.0022 & 0.0026 & 0.0017 \\
\hline & STD & 0.0687 & 0.0646 & 0.0721 \\
\hline \multirow{4}{*}{ NONDISC } & MEAN & $-0.0009 * * *$ & $0.0012 * * *$ & $-0.0065 * * *$ \\
\hline & MEDIAN & -0.0027 & 0.0027 & -0.0066 \\
\hline & STD & 0.0163 & 0.0162 & 0.0154 \\
\hline & $\mathrm{N}$ & 21232 & 9858 & 11374 \\
\hline
\end{tabular}

a) The notation * in panel A indicates that the specified business cycle is transitory (i.e., only 1 quarter).

b) The notation *** of mean value in panel B indicates the significance at level $1 \%$ (two tailed) of $t$-statistics. $T$-statistics is calculated as the mean value scaled by its standard error.

c) Definitions

EXP : Expansion (when the cycle variation value of CCI is above 100 points)

$R E C:$ Recession (when the cycle variation value of CCI is below 100 points)

$E A R N$ : Quarterly net income from income statement

$A C C$ : Quarterly total accruals, which is measured as net income less cash flow from operating activities (CFO)

$C F O$ : Quarterly cash flow from operating activities

$D I S C$ : Quarterly discretionary accruals estimated by the modified Jones model (Dechow et al., 1995)

NONDISC : Quarterly non-discretionary accruals estimated by the modified Jones model (Dechow et al., 1995)

Table 3 presents a correlation matrix of the current earnings with the prior quarter's earnings components. A correlation coefficient between earnings in period $t$ and earnings in period $t-1$ is 0.557 (Pearson) and 0.693 (Spearman). Prior quarter's accruals are positively associated with current earnings $(0.206,0.161)$ and cash flows from operations are also positively, and more strongly, related to current earnings $(0.226,0.276)$. As expected, we find a strong negative correlation between accruals and cash flows from operations $(-0.699,-0.728)$. Interestingly, prior quarter's discretionary accruals have a stronger correlation with current earnings $(0.202,0.156)$ compared to a correlation between non-discretionary accruals and earnings $(0.041,0.031)$. This result may be attributable to the correlation analysis with a lack of control variables. 
Table 3. Correlation Matrix $(\mathrm{N}=21,232)$

\begin{tabular}{|c|c|c|c|c|c|c|}
\hline & $E A R N_{t}$ & $E A R N_{t-1}$ & $A C C_{t-1}$ & $\mathrm{CFO}_{t-1}$ & $D_{I S C_{t-1}}$ & $N O N D I S C_{t-1}$ \\
\hline$E A R N_{t}$ & 1 & $\begin{array}{c}0.557 \\
(<.0001)\end{array}$ & $\begin{array}{c}0.206 \\
(<.0001)\end{array}$ & $\begin{array}{c}0.226 \\
(<.0001)\end{array}$ & $\begin{array}{c}0.202 \\
(<.0001)\end{array}$ & $\begin{array}{c}0.041 \\
(<.0001)\end{array}$ \\
\hline$E A R N_{t-1}$ & $\begin{array}{c}0.693 \\
(<.0001)\end{array}$ & 1 & $\begin{array}{c}0.408 \\
(<.0001)\end{array}$ & $\begin{array}{c}0.367 \\
(<.0001)\end{array}$ & $\begin{array}{c}0.413 \\
(<.0001)\end{array}$ & $\begin{array}{c}0.027 \\
(<.0001)\end{array}$ \\
\hline$A C C_{t-1}$ & $\begin{array}{c}0.161 \\
(<.0001)\end{array}$ & $\begin{array}{c}0.178 \\
(<.0001)\end{array}$ & 1 & $\begin{array}{l}-0.699 \\
(<.0001)\end{array}$ & $\begin{array}{c}0.971 \\
(<.0001)\end{array}$ & $\begin{array}{c}0.235 \\
(<.0001)\end{array}$ \\
\hline$C F O_{t-1}$ & $\begin{array}{c}0.276 \\
(<.0001)\end{array}$ & $\begin{array}{c}0.439 \\
(<.0001)\end{array}$ & $\begin{array}{l}-0.728 \\
(<.0001)\end{array}$ & 1 & $\begin{array}{l}-0.666 \\
(<.0001)\end{array}$ & $\begin{array}{l}-0.218 \\
(<.0001)\end{array}$ \\
\hline$D I S C_{t-1}$ & $\begin{array}{c}0.156 \\
(<.0001)\end{array}$ & $\begin{array}{c}0.186 \\
(<.0001)\end{array}$ & $\begin{array}{c}0.941 \\
(<.0001)\end{array}$ & $\begin{array}{l}-0.678 \\
(<.0001)\end{array}$ & 1 & $\begin{array}{l}-0.003 \\
(0.705)\end{array}$ \\
\hline$N O N D I S C_{t-1}$ & $\begin{array}{c}0.031 \\
(<.0001)\end{array}$ & $\begin{array}{l}-0.011 \\
(0.100)\end{array}$ & $\begin{array}{c}0.259 \\
(<.0001)\end{array}$ & $\begin{array}{l}-0.225 \\
(<.0001)\end{array}$ & $\begin{array}{l}-0.014 \\
(0.038)\end{array}$ & 1 \\
\hline
\end{tabular}

a) Pearson correlation results are indicated in right of the empty diagonal and spearman correlation results in left. All variables in this table are defined in Table 2 and subscript $t$ - 1 represents the prior quarter of $t$ quarter. $P$-values are shown in the parentheses.

\section{Test Results}

Table 4 presents the results of earnings persistence for two phases of business cycle. ${ }^{13}$ Panel A reports the results of regression analysis and Panel B summarizes the results that correspond to our hypothesis 1 \& 2 . Model 1 provides the results that earnings persistence in expansionary periods is higher than recessionary periods. Specifically, the incremental effect of recession on earnings persistence $\left(\alpha_{3}\right)$ is negative and statistically significant $(-0.2418, t$-statistics $=-2.83)$. Model 2 also confirms the well-researched phenomena that cash flows are more persistent than accruals. The persistence of cash flows one period ahead (0.5690) is higher than that of accruals (0.5492).

Interestingly, the results of model 3 regression indicate that cash flows are no longer more persistent than accruals when the business cycle is included in the model. The persistence of cash flows one period ahead (0.7086) is relatively lower compared to accruals persistence $(0.7197)$ in expansions, whereas the persistence of cash flows $(0.4938)$ is relatively higher compared to accruals persistence $(0.4560)$ in recessions. ${ }^{14}$ This finding implies that the persistence of earnings components (cash flows and accruals) changes with macroeconomic conditions, supporting hypothesis 1 .

We also examine the changes in persistence of earnings components across the business cycle. As predicted, the results of model 3 show that the magnitude of a decline in accruals persistence $\left(-0.2637\right.$ of $\left.\alpha_{3}\right)$ is larger than that in cash flows persistence $\left(-0.2148\right.$ of $\left.\alpha_{5}\right)$ when going from an expansion to a recession. This result supports the logical ground for hypothesis 2 which suggests that accruals component of earnings moves with the state of the economy in a less correlated fashion relative to cash flows component.

\footnotetext{
${ }^{13}$ For the regression analysis, OLS regression is implemented for estimation of coefficient and significance test ( $t$-statistics) of regression coefficient is derived by using firm clustering robust standard error to control the cross sectional correlation (Petersen, 2009) with the possibility of time serial autocorrelation bias except for model 2 regression. Model 2 regression is implemented by two dimensional clustering regression adjusting both cross sectional and time serial correlation (Thompson, 2011).

${ }^{14}$ Dechow and Ge (2006) document that higher persistence in accruals is related to the higher magnitude of accruals. Therefore, we conjecture that our results that earnings persistence of accruals is higher than that of cash flow in expansion are attributable to an increase in accruals due to higher macroeconomic productivity (investment and production) during expansionary period.
} 
Table 4. Earnings Persistence for Two Phases of Business Cycle

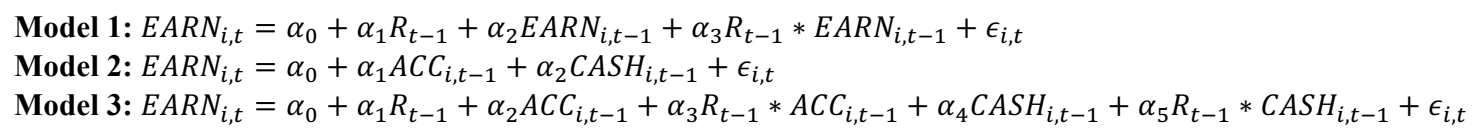

\begin{tabular}{|c|c|c|c|}
\hline \multicolumn{4}{|c|}{ Panel A. Regression Analysis Results } \\
\hline Variables & MODEL 1 & MODEL 2 & MODEL 3 \\
\hline \multirow{2}{*}{ INTERCEPT } & 0.0081 & 0.0111 & 0.0082 \\
\hline & $(10.27)^{* * *}$ & $(4.32) * * *$ & $(10.55)^{* * *}$ \\
\hline \multirow{2}{*}{$R$} & 0.0049 & & 0.0040 \\
\hline & $(1.81)^{*}$ & & $(1.83)^{*}$ \\
\hline \multirow{2}{*}{$E A R N_{t-1}$} & 0.7134 & & \\
\hline & $(30.65)^{* * *}$ & & \\
\hline \multirow{2}{*}{$R^{*} E A R N_{t-1}$} & -0.2418 & & \\
\hline & $(-2.83) * * *$ & & \\
\hline \multirow{2}{*}{$A C C_{t-1}$} & & 0.5492 & 0.7197 \\
\hline & & $(4.07)^{* * *}$ & $(27.53)^{* * *}$ \\
\hline \multirow{2}{*}{$R^{*} A C C_{t-1}$} & & & -0.2637 \\
\hline & & & $(-2.88)^{* * *}$ \\
\hline \multirow{2}{*}{$C A S H_{t-1}$} & & 0.5690 & 0.7086 \\
\hline & & $(4.56) * * *$ & $(32.72)^{* * *}$ \\
\hline \multirow{2}{*}{$R^{*} C A S H_{t-1}$} & & & -0.2148 \\
\hline & & & $(-3.06)^{* * *}$ \\
\hline $\mathrm{N}$ & 21232 & 21232 & 21232 \\
\hline Adj $\mathrm{R}-\mathrm{sq}$ & $32.35 \%$ & $31.04 \%$ & $32.46 \%$ \\
\hline Firm clustered SE & YES & YES & YES \\
\hline Period clustered SE & NO & YES & NO \\
\hline
\end{tabular}

Panel B. Comparison of Persistence in Earnings for Earnings Components

\begin{tabular}{lcccc}
\hline & Unconditioned & EXP & REC & EXP-REC \\
\hline$E A R N$ & & 0.7134 & 0.4716 & 0.2418 \\
$A C C$ & 0.5492 & 0.7197 & 0.4560 & 0.2637 \\
$C A S H$ & 0.5690 & 0.7086 & 0.4938 & 0.2148 \\
\hline
\end{tabular}

H1: (1) Earnings persistence in EXP : Accruals (0.7197) > Cash flows (0.7086)

H1: (2) Earnings persistence in REC : Cash flows (0.4938) > Accruals (0.4560)

H2: Incremental change from EXP to REC : Accruals (0.2637) > Cash flows (0.2148)

a) All variables in this table are defined in Table 2 and subscript $t$ - 1 represents the prior quarter of $t$ quarter.

b) The notation $* * *, * *$, and $*$ of the coefficients indicates the significance at level $1 \%, 5 \%$, and $10 \%$ (two tailed) of $t$-statistics, respectively.

Table 5 reports the results when we decompose total accruals into discretionary and non-discretionary accruals in Model 4 \& 5. The results for regression of Model 4 show that the persistence in both cash flows $(0.5719$ of $\left.\alpha_{3}\right)$ and non-discretionary accruals $\left(0.6555\right.$ of $\left.\alpha_{2}\right)$ are higher than the persistence in discretionary accruals $(0.5450$ of $\alpha_{1}$ ). The persistence of non-discretionary accruals one period ahead is still higher than cash flows both in expansions $(0.8108>0.7116)$ and in recessions $(0.5632>0.4950)$ in Model 5 . In addition, the results for Model 5 indicate that discretionary accruals are more persistent than cash flows during expansionary periods $\left(0.7159\right.$ of $\alpha_{2}>$ 0.7116 of $\alpha_{6}$ ), whereas cash flows are more persistent than discretionary accruals during recessionary periods $\left(0.4950\right.$ of $\alpha_{6}-\alpha_{7}>0.4520$ of $\left.\alpha_{2}-\alpha_{3}\right)$.

These results have several implications for the persistence of earnings components over the macroeconomic cycle. First, the persistence in discretionary accruals, non-discretionary accruals, and cash flows varies with the phase of business cycle, supporting our hypothesis 1 when total accruals are decomposed into two components (discretionary and non-discretionary accruals). Second, the changes in persistence over the macroeconomic cycle are differential across individual earnings components, consistent with our hypothesis 2 . Specifically, when going from an expansion to a recession, a decline in persistence of discretionary accruals $\left(0.2639\right.$ of $\left.\alpha_{3}\right)$ is greater than that in non-discretionary accruals $\left(0.2476\right.$ of $\left.\alpha_{5}\right)$ and cash flows $\left(0.2161\right.$ of $\left.\alpha_{7}\right)$ in Model 5 . This implies that discretionary 
accruals are the most influential factor contributing to the variation in earnings persistence over the business cycle because discretionary accruals are likely to move in a less correlated manner with the macroeconomic condition due to operational uncertainty, earnings management, and so on. Taken together, the results in Table 4 and Table 5 suggest that the macroeconomic cycle is a crucial determinant of earnings persistence; therefore, it needs to be cautiously considered in predicting a firm's future earnings.

Table 5. Earnings Persistence for Two Phases of Business Cycle: Accruals Decomposition

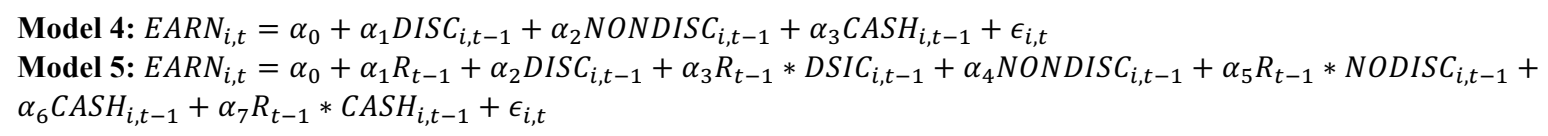

\begin{tabular}{|c|c|c|}
\hline \multicolumn{3}{|c|}{ Panel A: Regression Analysis Results } \\
\hline MODEL 4 & MODEL 4 & MODEL 4 \\
\hline INTERCEPT & $\begin{array}{c}0.0114 \\
(4.27)^{* * *} \\
\end{array}$ & $\begin{array}{c}0.0081 \\
(10.38)^{* * *}\end{array}$ \\
\hline$R$ & & $\begin{array}{c}0.0048 \\
(1.87)^{*} \\
\end{array}$ \\
\hline \multicolumn{3}{|l|}{$E A R N_{t-1}$} \\
\hline \multicolumn{3}{|l|}{$R^{*} E A R N_{t-1}$} \\
\hline$D I S C_{t-1}$ & $\begin{array}{c}0.5450 \\
(4.01)^{* * *}\end{array}$ & $\begin{array}{c}0.7159 \\
(27.23)^{* * *}\end{array}$ \\
\hline$R^{*} D I S C_{t-1}$ & & $\begin{array}{c}-0.2639 \\
(-2.84)^{* * *}\end{array}$ \\
\hline$N O N D I S C_{t-1}$ & $\begin{array}{c}0.6555 \\
(5.45)^{* * *}\end{array}$ & $\begin{array}{c}0.8108 \\
(22.30)^{* * *}\end{array}$ \\
\hline$R^{*} N O N D I S C_{t-1}$ & & $\begin{array}{c}-0.2476 \\
(-4.14) * * *\end{array}$ \\
\hline$C A S H_{t-1}$ & $\begin{array}{c}0.5719 \\
(4.62)^{* * *}\end{array}$ & $\begin{array}{c}0.7116 \\
(32.93)^{* * *}\end{array}$ \\
\hline$R^{*} C A S H_{t-1}$ & & $\begin{array}{c}-0.2161 \\
(-3.15)^{* * *}\end{array}$ \\
\hline $\mathrm{N}$ & 21232 & 21232 \\
\hline Adj R-sq & $31.15 \%$ & $32.54 \%$ \\
\hline Firm clustered SE & YES & YES \\
\hline Period clustered SE & YES & NO \\
\hline
\end{tabular}

a) All variables in this table are defined in Table 2 and subscript $t$-1 represents the prior quarter of $t$ quarter.

b) The notation $* * * * *$, and $*$ of the coefficients indicates the significance at level $1 \%, 5 \%$, and $10 \%$ (two tailed) of $t$-statistics, respectively.

c) The results of first row in Panel B are induced by regression analysis of Model 1 in Table 4.

\section{Additional Analyses}

Additionally, we consider the possibility that the results may change depending on the way we break down the phases of business cycle. For instance, a firm's operating environment is likely to be unstable during transitory periods (i.e., credit crunch period from an expansion to a recession, recovery period which is the reversal) because these phases of macroeconomic cycle are temporary (Kwon et al., 2012). If such uncertainty is reflected in accruals, persistence of earnings may decline to a greater extent during transitory periods. In particular, the magnitude of accruals is likely to change dramatically because a firm's normal operating activities and managerial discretion under accrual accounting system will adapt to a new phase of macroeconomic cycle. For example, managers may not be able to cope with unexpected changes in demands promptly or they could manipulate corporate earnings (e.g., income smoothing, taking a big bath) to avoid reporting losses or to increase future earnings in the long run when the state of the economy changes between a recession and an expansion. 
Therefore, we test our hypotheses by splitting the business cycle further into four aspects. Following Tomy (2012), we define two transition periods as two quarters before and after a recession period. Specifically, T1 indicates the period of two quarters before entering a recessionary period and $\mathrm{T} 2$ indicates the period of two quarters after a recession. Thus, we consider the four phases of business cycle: expansion, transition I (T1), transition II (T2), and recession.

Table 6 presents the further test results when we consider four phases of business cycle. Similar to the test results for two phases of business cycle, we still show that accruals (cash flows) are more persistent than cash flows (accruals) during expansions (recessions). In Model 7, the persistence of cash flows (0.8195) one period ahead is relatively lower compared to accruals persistence (0.8354) in expansions, whereas the persistence of cash flows (0.4938) is relatively higher compared to accruals persistence (0.4560) in recessions. Also, the magnitude of changes in earnings persistence across the business cycle is larger for accruals than for cash flows. ${ }^{15}$

When total accruals are decomposed into two components in Model 8, non-discretionary accruals are more persistent than cash flows and discretionary accruals in all phases of the business cycle. However, the relative magnitude of changes in persistence of earnings components differs from the test results based on the two phases of business cycle in Model 5 (Table 5). When the economy shrinks (i.e., from a transitory period to a recession), we find that a decline in persistence is largest for discretionary accruals $(0.1786)$, whereas when the economy recovers (i.e., from a recession to a transitory period), an increase in persistence is largest for non-discretionary accruals $(0.1388) .{ }^{16}$ This finding indicates the differential effects of macroeconomic cycle on the persistence of individual earnings components, suggesting that such effects need to be considered in estimating earnings persistence.

\footnotetext{
${ }^{15}$ Panel B in Table 6 shows that the incremental change in accruals persistence between the transitory periods (i.e., from expansion to T1, from $\mathrm{T} 1$ to recession, and from recession to T2) is $0.2024,0.1770$, and -0.0907 , respectively, which are larger than that in cash flows persistence $(0.1901,0.1356$, and -0.0473$)$. The test results are summarized in Panel C.

${ }^{16}$ This result suggests that non-discretionary accruals are directly affected by macroeconomic condition and move in a more correlated fashion with business cycle than other earnings components, indicating that the persistence of non-discretionary accruals is high in all phases of business cycle. However, when the economy shrinks (i.e., from a transitory period to a recession), we speculate that a higher change in persistence of discretionary accruals is likely to be related to earnings management in order to prevent a dramatic decline of earnings in recessionary period.
} 
Table 6. Earnings Persistence for Four Phases of Business Cycle

\begin{tabular}{|c|c|c|c|}
\hline \multicolumn{4}{|c|}{ Panel A. Regression Analysis Results } \\
\hline MODEL 7 & MODEL 7 & MODEL 7 & MODEL 7 \\
\hline INTERCEPT & $\begin{array}{c}0.0045 \\
(3.56)^{* * *}\end{array}$ & $\begin{array}{c}0.0046 \\
(3.75)^{* * *}\end{array}$ & $\begin{array}{c}0.0043 \\
(3.45)^{* * *}\end{array}$ \\
\hline$R$ & $\begin{array}{c}0.0085 \\
(2.97)^{* * *}\end{array}$ & $\begin{array}{c}0.0076 \\
(3.32)^{* * *}\end{array}$ & $\begin{array}{c}0.0086 \\
(3.15)^{* * *}\end{array}$ \\
\hline$T 1$ & $\begin{array}{c}0.0046 \\
(2.43)^{* *}\end{array}$ & $\begin{array}{c}0.0046 \\
(2.49)^{* *}\end{array}$ & $\begin{array}{c}0.0049 \\
(2.63)^{* * *}\end{array}$ \\
\hline$T 2$ & $\begin{array}{c}0.0098 \\
(5.11)^{* * *}\end{array}$ & $\begin{array}{c}0.0098 \\
(5.16)^{* * *}\end{array}$ & $\begin{array}{c}0.0100 \\
(5.33)^{* * *}\end{array}$ \\
\hline$E A R N_{t-1}$ & $\begin{array}{c}0.8264 \\
(23.42)^{* * *}\end{array}$ & & \\
\hline$R * E A R N_{t-1}$ & $\begin{array}{c}-0.3548 \\
(-3.97)^{* * *}\end{array}$ & & \\
\hline$T 1 * E A R N_{t-1}$ & $\begin{array}{c}-0.1953 \\
(-3.19)^{* * *}\end{array}$ & & \\
\hline$T 2 * E A R N_{t-1}$ & $\begin{array}{c}-0.2810 \\
(-4.93)^{* * *}\end{array}$ & & \\
\hline$A C C_{t-1}$ & & $\begin{array}{c}0.8354 \\
(21.01)^{* * *}\end{array}$ & \\
\hline$R^{*} A C C_{t-1}$ & & $\begin{array}{c}-0.3794 \\
(-3.94)^{* * *}\end{array}$ & \\
\hline$T 1 * A C C_{t-1}$ & & $\begin{array}{c}-0.2024 \\
(-4.53)^{* * *}\end{array}$ & \\
\hline$T 2 * A C C_{t-1}$ & & $\begin{array}{c}-0.2821 \\
(-4.53) * * *\end{array}$ & \\
\hline$D I S C_{t-1}$ & & & $\begin{array}{c}0.8306 \\
(20.83)^{* * *}\end{array}$ \\
\hline$R * D I S C_{t-1}$ & & & $\begin{array}{c}-0.3786 \\
(-3.88)^{* * *}\end{array}$ \\
\hline$T 1 * D I S C_{t-1}$ & & & $\begin{array}{c}-0.2000 \\
(-2.94) * * *\end{array}$ \\
\hline$T 2 * D I S C_{t-1}$ & & & $\begin{array}{c}-0.2829 \\
(-4.49)^{* * *}\end{array}$ \\
\hline$N O N D I S C_{t-1}$ & & & $\begin{array}{c}0.9920 \\
(17.39)^{* * *}\end{array}$ \\
\hline$R^{*} N O N D I S C_{t-1}$ & & & $\begin{array}{c}-0.4288 \\
(-5.74)^{* * *}\end{array}$ \\
\hline$T 1 * N O N D I S C_{t-1}$ & & & $\begin{array}{c}-0.3171 \\
(-3.41)^{* * *}\end{array}$ \\
\hline$T 2 * N O N D I S C_{t-1}$ & & & $\begin{array}{c}-0.2900 \\
(-3.48)^{* * *}\end{array}$ \\
\hline$C A S H_{t-1}$ & & $\begin{array}{c}0.8195 \\
(25.56)^{* * *}\end{array}$ & $\begin{array}{c}0.8261 \\
(25.73)^{* * *}\end{array}$ \\
\hline$R^{*} C A S H_{t-1}$ & & $\begin{array}{c}-0.3257 \\
(-4.41)^{* * *}\end{array}$ & $\begin{array}{c}-0.3306 \\
(-4.57)^{* * *}\end{array}$ \\
\hline$T 1 * C A S H_{t-1}$ & & $\begin{array}{c}-0.1901 \\
(-3.35)^{* * *}\end{array}$ & $\begin{array}{c}-0.1956 \\
(-3.43)^{* * *}\end{array}$ \\
\hline$T 2 * C A S H_{t-1}$ & & $\begin{array}{c}-0.2784 \\
(-5.03)^{* * *}\end{array}$ & $\begin{array}{c}-0.2815 \\
(-5.11)^{* * *}\end{array}$ \\
\hline $\mathrm{N}$ & 21232 & 21232 & 21232 \\
\hline Adj R-sq & $32.83 \%$ & $32.93 \%$ & $33.03 \%$ \\
\hline Firm clustered SE & YES & YES & YES \\
\hline Period clustered SE & $\mathrm{NO}$ & $\mathrm{NO}$ & $\mathrm{NO}$ \\
\hline
\end{tabular}


(Table 6 continued)

Panel B. Comparison of Earnings Persistence for Model $6 \& 7$

\begin{tabular}{|c|c|c|c|c|c|c|c|c|}
\hline & & \multirow{2}{*}{$\operatorname{EXP(a)}$} & \multirow{2}{*}{ T1(b) } & \multirow{2}{*}{$\operatorname{REC}(c)$} & \multirow{2}{*}{ T2(d) } & \multicolumn{3}{|c|}{ Incremental effect } \\
\hline & & & & & & (a)-(b) & (b)-(c) & (c)-(d) \\
\hline$E A R N$ & & 0.8264 & 0.6311 & 0.4716 & 0.5454 & 0.1954 & 0.1594 & $(0.0738)$ \\
\hline$A C C$ & 0.5492 & 0.8354 & 0.6330 & 0.4560 & 0.5533 & 0.2024 & 0.1770 & $(0.0973)$ \\
\hline $\mathrm{CASH}$ & 0.5690 & 0.8195 & 0.6294 & 0.4938 & 0.5411 & 0.1901 & 0.1356 & $(0.0473)$ \\
\hline
\end{tabular}

(1) Earnings persistence in EXP(a) : NONDISC $>$ DISC $>$ CASH

H1 (2) Earnings persistence in T1(b) : NONDISC $>$ DISC $>$ CASH

(3) Earnings persistence in REC(c) : NONDISC $>$ CASH $>$ DISC

(4) Earnings persistence in T2(d) : NONDISC $>$ DISC $>$ CASH

(1) Incremental effect from EXP(a) to T1(b) : NONDISC $>$ DISC $>$ CASH

$\mathrm{H} 2$ (2) Incremental effect from T1(b) to REC(c) : DISC $>\mathrm{CASH}>\mathrm{NONDISC}$

(3) Incremental effect from REC(c) to T2(c) : NONDISC $>$ DISC $>$ CASH

(1) Earnings persistence in EXP(a) : NONDISC $>$ DISC $>$ CASH

Panel C: Comparison of Earnings Persistence for Model 6 - 8

\begin{tabular}{|c|c|c|c|c|c|c|c|c|}
\hline & & \multirow{2}{*}{$\operatorname{EXP}(a)$} & \multirow{2}{*}{ T1(b) } & \multirow{2}{*}{$\operatorname{REC}(c)$} & \multirow{2}{*}{$T 2(d)$} & \multicolumn{3}{|c|}{ Incremental effect } \\
\hline & & & & & & (a)-(b) & (a)-(b) & (a)-(b) \\
\hline$E A R N^{c)}$ & & 0.8264 & 0.6311 & 0.4716 & 0.5454 & 0.1954 & 0.1954 & 0.1954 \\
\hline$D I S C$ & 0.5450 & 0.8306 & 0.6306 & 0.4520 & 0.5477 & 0.2000 & 0.2000 & 0.2000 \\
\hline NONDISC & 0.6555 & 0.9920 & 0.6749 & 0.5632 & 0.7020 & 0.3171 & 0.3171 & 0.3171 \\
\hline
\end{tabular}

(1) Earnings persistence in EXP(a) : NONDISC $>$ DISC $>$ CASH

$\mathrm{H} 1$ (2) Earnings persistence in T1(b) : NONDISC $>$ DISC $>\mathrm{CASH}$

(3) Earnings persistence in REC(c) : NONDISC $>$ CASH $>$ DISC

(4) Earnings persistence in T2(d) : NONDISC $>$ DISC $>$ CASH

(1) Incremental effect from EXP(a) to T1(b) : NONDISC $>$ DISC $>$ CASH

(2) Incremental effect from T1(b) to REC(c) : DISC $>$ CASH $>$ NONDISC

(3) Incremental effect from REC(c) to T2(c) : NONDISC $>$ DISC $>$ CASH

a) All variables in this table are defined in Table 2 and subscript $t-1$ represents the prior quarter of $t$ quarter.

b) The notation $* * *, * *$, and $*$ of the coefficients indicates the significance at level $1 \%, 5 \%$, and $10 \%$ (two tailed) of $t$-statistics, respectively.

c) The results of first row in Panel $\mathrm{C}$ are based on the regression analysis of Model 6 in Table 5.

\section{CONCLUSIONS}

This study investigates the relation between earnings persistence and business cycle. Specifically, we examine whether the persistence of earnings components (operating cash flows, non-discretionary accruals and discretionary accruals) is systematically different over the business cycle and whether the changes in persistence across the state of the economy differ by individual earnings components.

We analyze earnings persistence over the business cycle by implementing some regressions for the relation between current earnings and the prior quarter's earnings or earnings components across the phases of business cycle. Our sample is based on KOSPI and KOSDAQ listed firms between 2002 and 2013. Business cycle is measured using the cycle variation value of Coincident Composite Index data obtained from the Korea National Statistics Office.

We show that accruals (cash flows) are more persistent than cash flows (accruals) during expansions (recessions). Also, we find that a decline in accruals persistence is greater than that in cash flows persistence when going from an expansion to a recession. When total accruals are decomposed into non-discretionary and discretionary accruals based on the modified Jones model (Dechow et al., 1995), we find that non-discretionary accruals are more persistent than cash flows and discretionary accruals in both expansions and recessions. In addition, when going from an expansion to a recession, a decline in persistence is largest for discretionary accruals, and it is smallest for cash flows.

Moreover, we show that the results based on two phases of business cycle still hold when we split the business cycle into four aspects (expansion, transition, recession, transition). Also, when the economy shrinks (i.e., 
from a transitory period to a recession), we find that a decline in persistence is largest for discretionary accruals, whereas when the economy recovers (i.e., from a recession to a transitory period), an increase in persistence is largest for non-discretionary accruals. This implies that the effects of macroeconomic cycle on the persistence of individual earnings components are differential.

Our findings provide several contributions. This study provides a new perspective to the complex interaction between firm valuation and macroeconomic conditions by documenting the earnings persistence variation over the business cycle. These results may be of interest to managers making decisions for firms, because they can make more efficient operational decisions by considering macroeconomic conditions. In addition, predicting future earnings with consideration of macroeconomic cycle could help capital market participants to decrease misevaluation of companies. Collectively, our finding suggests that macroeconomic variables are needed for researchers to be considered in studies on earnings persistence and other attributes of earnings.

\section{ACKNOWLEDGEMENTS}

This work was supported by the Ewha Womans University Research Grant of 2012.

\section{AUTHOR INFORMATION}

Sorah Park, Ph.D. in Accounting, is an Assistant Professor at Ewha School of Business, Ewha Womans University, Seoul, Korea. (Corresponding author)

Heejeong Shin is a Ph.D. student in Accounting at Ewha School of Business, Ewha Womans University, Seoul, Korea.

\section{DATA AVAILABILITY}

The data used in this study are available from public sources.

\section{REFERENCES}

Agarwal, V., \& Hess, D. (2012). Common factors in analysts' earnings revisions: the role of changing economic conditions. Available at SSRN 2024161.

Barth, M. E., Elliott, J. A., \& Finn, M. W. (1999). Market rewards associated with patterns of increasing earnings. Journal of Accounting Research, 37(2), 387-413.

Bradshaw, M., Richardson, S., \& Sloan, R. (2001). Do analysts and auditors use information in accruals. Journal of Accounting Research, 39(1), 45-74.

Chan, L., Karceski, J., \& Lakonishok, J. (2006). Analysts' conflicts of interest and biases in earnings forecasts. Journal of Financial and Quantitative Analysis, 42(4), 893-914.

Chen, C. 2013. Time-Varying earnings persistence and the delayed stock return reaction to earnings announcements. Contemporary Accounting Research, 30(2), 549-578.

Darrough, M., \& Russell, T. (2002). A positive model of earnings forecasts: Top down versus bottom up. Journal of Business, 75(1), 127-152.

Dechow, P., \& Schrand, C. (2004). Earnings quality. The Research Foundation of CFA Institute.

Dechow, P. M., \& Skinner, D. J. (2000). Earnings management: Reconciling the views of academics, practitioners, and regulators. Accounting Horizons, 14(2), 235-250.

Dechow, P., \& Ge, W., (2006). The Persistence of earnings and cash flows and the role of special Items: Implications for the accrual anomaly. Review of Accounting Studies, 11(2-3), 253-296.

Dechow, P. M., Sloan, R. G., \& Sweeney, A. P. (1995). Detecting earnings management. The Accounting Review, 70(2), 193-225.

Dechow, P. M., Ge, W., Larson, C.R., \& Sloan, R.G. (2008). Predicting material accounting manipulations. (Working Paper). University of California, Berkeley. 
Dechow, P. M., Ge, W., \& Schrand, C. (2010). Understanding earnings quality: A review of the proxies, their determinants and their consequences. Journal of Accounting and Economics, 50(2), 344-401.

DeFond, M. L., \& Park, C. (1997). Smoothing income in anticipation of future earnings. Journal of Accounting and Economics, 23(July), 115-140.

Dichev, I. D., Graham, J., Harvey, C. R., \& Rajgopal, S. (2013). Earnings quality: Evidence from the field. Journal of Accounting and Economics, 56(2). 1-33.

Easton, P., \& Zmijewski, M. (1989). Cross-sectional variation in the stock market response to accounting earnings announcements. Journal of Accounting and Economics, 11(2-3), 117-141.

Elliott, J. A., \& Shaw. W. H. (1988). Write-offs as accounting procedures to manage perceptions. Journal of Accounting Research, 26(Supplement), 91-126.

Erickson, M., \& Wang, S., (1999). Earnings management by acquiring firms in stock for stock mergers. Journal of Accounting and Economics, 27(2), 149-176.

Fields, T. D., Lys, T. Z., \& Vincent, L. (2001). Empirical research on accounting choice. Journal of Accounting and Economics, 31(1), 255-307.

Fairfield, P., Whisenant, J., \& Yohn, T. (2003). Accrued earnings and growth: Implications for future profitability and market mispricing. The Accounting Review, 78(1), 353-371.

Francis, J., LaFond, R., Olsson, P. M., \& Schipper, K. (2004). Costs of equity and earnings attributes. The Accounting Review, 79(4), 967-1010.

Goedhart, M., Raj, R., \& Saxena, A. (2010). Equity analysts: still too bullish. McKinsey Quarterly(April). McKinsey \& Company.

Guay, W., Kothari, S. P., \& Watts, R. L. (1996). A market-based evaluation of discretionary accrual models. Journal of Accounting Research, 34(3), 83-105.

Han, J. S. (2006). Let's play with statistics. Government Information Agency. [Printed in Korean]

Hann, R., Ogneva, M., \& Sapriza, H. (2012). Forecasting the macroeconomy: analysts versus economists. (Working paper). University of Maryland and University of Southern California.

Healy, P., \& Whalen, J. M. (1999). A Review of the earnings management literature and its implications for standard setting. Accounting Horizons, 13(4), 365-384.

Hess, D., \& Kreutzmann, D. (2010). Earnings expectations and macroeconomic conditions. (Working paper). University of Cologne.

Huang, X., Teoh, S. H., \& Y. Zhang. (2014). Tone management. The Accounting Review, 89(3), 1083-1113.

Hugon, A., Kumar, A., \& Lin, A. (2013). Analysts, macroeconomic news, and the benefit of in-house economists. (Working paper). Retrieved from http://ssrn.com/abstract=2249137.

Hutton, A., Lee, L., \& Shu, S. (2012). Do managers always know better? The relative accuracy of management and analyst forecasts. Journal of Accounting Research, 50(5), 1217-1244.

Johnson, M. (1999). Business cycles and the relation between security returns and earnings. Review of Accounting Studies, 4(2), 93-117.

Jones, J. (1991). Earnings management during import relief investigations. Journal of Accounting Research, 29(2), 193-228.

Kasznik, R., \& McNichols, M. F. (2002). Does meeting earnings expectations matter? Evidence from analyst forecast revisions and share prices. Journal of Accounting Research, 40(3), 727-59.

Kim, D., \& Qim, Y. (2010). Accruals quality, stock returns, and macroeconomic conditions. The Accounting Review, 85(3), 937-978.

Kormendi, R., \& Lipe, R. (1987). Earnings innovations, earnings persistence and stock returns. Journal of Business, 60(3), 323-345.

Kwon, S. Y., Choi, K. S., \& Kim, K. H. (2012). The association between management earnings forecasts and accruals in an uncertain corporate environment. Korea Business Review, 41(2), 311-348. [Printed in Korean]

Lee, C. H. (2010). The effect of business cycle on accruals persistence and accruals anomaly. (Dissertation). Incheon National University. [Printed in Korean]

Lev, B, \& Thiagarajan, R. (1993). Fundamental information analysis. Journal of Accounting Research, 31(2), 190215.

Linck, J. S., Netter, J. \& Tao, S. (2013). Can managers use discretionary accruals to ease financial constraints? Evidence from discretionary accruals prior to investment. The Accounting Review, 88(6), 2117-2143. 
McNichols, M. (2000). Research design issues in earnings management studies. Journal of Accounting and Public Policy, 19(4-5), 313-345.

Melumad, N. D., \& Nissim, D. (2009). Line-item analysis of earnings quality. Foundations and Trends in Accounting, 3(2-3), 87-221.

Mikhail, M., B. Walther, and R. Willis. 2003. The effect of experience on security analyst underreaction. Journal of Accounting and Economics 35(1): 101-116.

Myers, J. N., Myers, L. A. \& Skinner, D. J. (2007). Earnings momentum and earnings management. Journal of Accounting, Auditing and Finance, 22(2), 249-284.

Penman, S., \& Zhang, X. (2002). Accounting conservatism, the quality of earnings, and stock returns. The Accounting Review, 77(2), 237-264.

Petersen, M. (2009). Estimating standard errors in finance panel data sets: comparing approaches. Review of Financial Studies, 22(1), 435-480.

Richardson, S., Sloan, R., Soliman, M., \& Tuna, I. (2005), Accrual reliability, earnings persistence and stock prices. Journal of Accounting and Economics, 39(3), 437-485.

Richardson, S., Sloan, R., Soliman, M., \& Tuna, I. (2006). The implications of accounting distortions and growth for accruals and profitability. The Accounting Review, 81(3), 713-744.

Sloan, R. (1996). Do stock prices fully reflect information in accruals and cash flows about future earnings? The Accounting Review, 71(3), 289-315.

Subramanyam, K. (1996). The pricing of discretionary accruals. Journal of Accounting and Economics, 22(1), 249281.

Thompson, S. B. (2011). Simple formulas for standard errors that cluster by both firm and time. Journal of Financial Economics, 99(1), 1-10.

Tomy, R. E. (2012). Earnings persistence over the business cycle. (Working paper). Stanford University.

Xie, H. (2001). The mispricing of abnormal accruals. The Accounting Review, 76(3), 357-373. 


\section{NOTES}

